\title{
Posthumanism $=$ Posteducation: A Reply to Siân Bayne's Posthumanism: A Navigation Aid for Educators
}

\author{
Norm Friesen (Boise State University)
}

I have long been an interested observer of the emergence and development of posthuman, actor-network and sociomaterial approaches to education and educational technology in the UK and elsewhere. I have seen friends and colleagues whom I respect devote a great deal of their time and effort to these approaches.

I have always had misgivings about the suitability and productivity of these frameworks for education and critical theorizing. I am now grateful to both Siân Bayne and on_education for encouraging me to formulate these misgivings in response to Bayne's "Posthumanism: A navigation aid for educators." (I have also taken the liberty of including Stefan Herbrechter's "Posthumanism and the Ends of Education" in my comments, an article which immediately follows Bayne's in the same issue.)

Posthuman, actor-network and socio-material approaches (subsequently designated "posthumanism") propose to rethink education, engagement, development, ecology, and many other concerns in the light of "the end of a certain conception of the human'" (Hayles, as cited in Bayne, p. 2). This conception is one in which humans see themselves "as autonomous beings exercising their will through individual agency and choice"" (ibid). It is, in other words, autonomy and the exercise of agency, will and choice that are seen as at an end, that are "posted" in posthumanism. Instead of being autonomous, posthumanists say we must see ourselves as "entangled" with the world and with technology; and see these non-human "actors" as exercising agency over us. Through this bold reversal, posthumanism is said to undo "the separation of matter from meaning, the object from the subject", (Edwards, 2010; as cited in Bayne, p. 4), as helping us "develop a new, a better and more ecological relationship with our planet" (Herbrechter, p. 3), and as deconstructing "the still widely-held assumption that [...] digital technology in education is largely instrumental [...] a 'tool' to [...] make education 'better'" (Bayne, p. 4). In these and other ways, posthumanism brings elements of feminism, environmentalism, postcolonial studies and technology critique together. Through its denial of the centrality of human agency and choice, posthumanism also requires us to reconceptualize the most fundamental assumptions and understandings of education itself.

The challenging and boundary-breaking spirit of posthumanist thought is itself of value for education. Posthumanism however presents many deeply problematic implications for the discourses and practices of education and for the discipline itself.
It is certainly intellectually interesting to conceive of oneself as an "actant" entangled in a web of human and non-human actors - as actor network theory, for example, does. Such conceptions have led scholars to some valuable insights. However, the loss of claims to the "autonomous exercise" of "will" and "choice" that come with posthumanism could not be more detrimental to ways of acting and reflecting in education. Education, from the Latin educere - to "bring out, lead forth" implies someone acting upon another, typically an older person drawing out or in some sense leading a younger. To say that such action requires a significant and responsible exercise of agency, decision, intention and will is to state the obvious. What might be less obvious, though, is that such agency and intention is also expressed in the widest range of educational actions, plans and designs - from everyday acts of communication and instruction to the design of the school, classroom and the lesson plan. Practically speaking, education, its engagements, artifacts and discourses are all unavoidably purposive and normative. To see a classroom as "not constructed by humans [...] but rather constituted through [...] complex relations between entities in a collective field of engagement" as posthumanism does (Russell, cited by Bayne, p. 3), is to miss the point. It is to render the classroom's normative and purposive character, that which actually makes it pedagogical, invisible. Classrooms and teachers' arrangements of them are of course carefully and intentionally set up for purposes of teaching, learning, study and collaboration. Referring, for example, to the traditional classroom, Sommer (1969) writes:

The present rectangular room with its straight rows of chairs and wide windows was intended to provide for ventilation, light, quick departure, ease of surveillance, and a host of other legitimate needs as they existed in the early 1900's [...]. The typical long narrow shape [of these classrooms, N.F.] resulted from a desire to get light across the room. The front of each room was determined by window location, since pupils had to be seated so that window light came over the left shoulder (p. 58).

The classroom, in short, is decidedly constructed by humans, for normative human ends. Similar care, forethought and agency are evident in many other educational arrangements, conventions and practices - 
even if they are not explicitly recognized by those engaged with(in) them. To whatever extent it denies "individual agency and choice," posthumanism deliberately and systematically excludes these and many other essentially educational purposeful and normative arrangements, acts and practices from its purview.

Such an evacuation of purpose and norm from our everyday lives would leave us bereft. Not only are our roles in civil society (e.g. as an automobile driver or educational researcher) defined in terms of accountability and responsibility, we constantly understand our actions - and those of others - in terms of agency and purpose. The subject-verb-object structure of our language could not make this clearer. Moreover, without a robust account of agency and responsibility, we lose precious critical purchase to work toward any political or normative agenda - whether it be to undermine the Cartesian subject/object divide, or to advocate for ecological sustainability or for education as a "public good." One specific example is mounting resistance to the introduction of Facebook-like "personalized learning" technologies in classrooms. Such attempts, as Bayne herself writes, appear from the perspective of posthumanism as "an emergent property of a sociomateriality," one that is "beyond the control of individual human agency" (p. 4). Questions of politics, critique and resistance, like those of education itself, are inescapably purposive and normative, and thus truncated from the posthuman point of view.

My impression, however, is that posthumanists would admit to some if not much of this - but perhaps in not so many words. Herbrechter, for example, recognizes that posthumanism's rejection of the "moral human being [...] goes to the heart of education." "Humanism," Herbrechter continues, "basically loses its addressee" (p. 3). One could say that the same thing happens to posthumanism in education as well.

So what or whom is educational posthumanism addressing? What do posthumanists propose for education? The best way to answer this question is to see what they say about humanism itself — and by extension about its projects, including education. The answer is that they want to "get out of humanism... actually to break it up," to create the conditions for "something else to be able to take place" (Herbrechter, p. 1). They see in this the opportunity for " "experimentation and, by implication, [for] taking (and being allowed to take) risks" in educational contexts (Whatmore, as cited in Bayne, p. 5).

This paucity of recommendations for education is not by chance. It is because in denying or "posting" the human - to whatever extent it might do this posthumanism also denies education. In departments of philosophy, posthumanism would appear as an ontology, as a type of philosophical (anti-)anthropology that might well have its place in theoretical discourse; but in education, it appears largely as oppositional. This means that it can only remain dependent - generally parasitically so — on the dominant "affirmative" constitution of the field. For better or worse, education cannot be anything else but predominantly human. It is, after all about "subjectification", as both Foucault and theories of Bildung and formation would have it. To the degree that posthumanisms deny human agency and responsibility, they also "post" the project of education; to the degree that they affirm these human characteristics, they cannot be called posthumanist.

After all, are we are educators, not philosophers. We are of necessity in sustained engagement with political, theoretical and also practical questions of education. We must therefore adopt and develop frameworks consistent with this engagement, rather than ones that would obscure or deny it. These may well be frameworks that urge us to rethink the significance of the human - a task that has already been initiated in "educational" or "pedagogical anthropology" (e.g., Wulf 2002; Koerrenz 2017). However, these frameworks would also need to account for the purposive and normative nature of education itself, and for our active role within it. For I am certain that such "human" education will indeed continue - with or without 
${ }^{1}$ I readily admit that I am engaging in vast oversimplifications in bringing posthuman, actor-network and socio-material approaches together in this way-and also by taking only two articles as representative of an expansive and sophisticated literature. However, I believe that my remarks are relevant to the degree that this literature seeks to "de-center" the human and marginalize possibilities for human agency.

\section{References}

Koerrenz, R. (2017). Existentialism and education: An introduction to Otto Friedrich Bollnow. Boston, MA: Palgrave. Sommer, R. (1969). Personal Space: The behavioral basis of design. New York, NY: Prentice Hall. Wulf, C. (2002). Anthropology of education. London: LIT. Retrieved from http://learningspaces.org/files/Wulf_Anthropology_of_Education.pdf

\section{Recommended Citation}

Friesen, N. (2018). Posthumanism = Posteducation: A reply to Siân Bayne's Posthumanism: A navigation aid for educators. On Education. Journal for Research and Debate, 1(2). https://doi.org/10.17899/on_ed.2018.2.8

About the Author

Norm Friesen is a Professor in the Department Educational Technology at the College of Education, Boise State University. He recently published The Textbook and the Lecture: Education in the Age of New Media with Johns Hopkins University Press and is currently co-authoring Rehumanizing Education: Towards a Hermeneutic Pedagogy. 